\title{
Studies on the Electrochemical Disinfection of Water Containing Escherichia coli using a Dimensionally Stable Anode
}

\author{
Isabel Celeste Caíres Pereira Gusmão ${ }^{1}$, Peterson Bueno Moraes ${ }^{2 *}$ and Ederio Dino Bidoia ${ }^{3}$ \\ ${ }^{1,3}$ Laboratório de Pesquisas Ambientais; Departamento de Bioquímica e Microbiologia; Instituto de Biociência; \\ Universidade Estadual Paulista; Av. 24-A, n.1515; 13506-900; Rio Claro - SP - Brasil. ${ }^{2}$ Laboratório de \\ Desenvolvimento de Sistemas para Saneamento Ambiental; Faculdade de Tecnologia; Universidade de Campinas; \\ 13484-332; Limeira - SP - Brasil
}

\begin{abstract}
The aim of this work was to investigate the disinfectant effect of electrolysis on chlorine-free water, artificially contaminated with Escherichia coli (CCT-1457) and to evaluate the bactericidal activity of electrolysis and kinetic behavior of a single-cell reactor, with a DSA (Dimensionally Stable Anode) electrode to develop a scaled-up

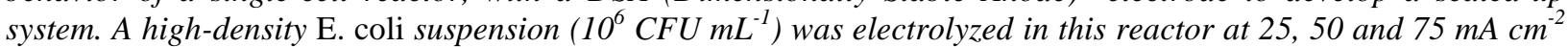
for up to $60 \mathrm{~min}$, at flow rates of 200 and $500 \mathrm{~L} \mathrm{~h}^{-1}$. Bacterial survival fell by $98.9 \%$ without addition of chlorinated compounds and a power consumption rate not more than $5.60 \mathrm{kWh} \mathrm{m}^{-3}$ at flow rate of $200 \mathrm{~L} \mathrm{~h}^{-1}$ and $75 \mathrm{~mA} \mathrm{~cm}^{-2}$. The process produced a germicidal effect that reached this inactivation rate within a relatively short contact time. Also, a solution of electrolyzed $0.08 \mathrm{M} \mathrm{Na}_{2} \mathrm{SO}_{4}$ added to the inoculum showed residual bactericidal effect. The efficiency of disinfection was regulated by both the contact time and current density applied, and a kinetic function for the survival rate was developed for the purpose of scaling up.
\end{abstract}

Key words: $E$. coli inactivation, electrochemical treatment, electrolysis of microorganisms, electroxidation process, bactericidal effect, DSA oxide electrode

\section{INTRODUCTION}

In general, the microbial cell can be damaged as a consequence of adverse conditions, such as osmotic pressure difference, electric field, desiccation, heating, chilling, chemicals, oxidants or ultraviolet radiation. Based on such mechanisms, many of drinking water treatment systems have been developed and tested, using osmosis, flocculation, UV light irradiation (Kalisvaart, 2004), ultrasonic irradiation, ozone, hydrogen peroxide, photolysis, homogeneous and heterogeneous photocatalysis, radiolysis, biocidal agents, high-voltage pulses (Lubicki and Jayaram, 1997), electrohydraulic discharges, electrolysis, and combined techniques. However, recent research has shown that some treatment methods, such as chlorination and UV radiation with lowpressure lamps, are not fully efficient, as some pathogens are capable of "reactivation" or "recovery"; these include Escherichia coli, Campylobacter jejuni, enteric viruses such as rotavirus, calicivirus, and astrovirus and the parasites Cryptosporidium parvum, Giardia

*Author for correspondence: peterson@ft.unicamp.br 
lamblia and microsporidia (Szewzyk et al., 2000). Moreover, the chlorination of drinking water may affect its taste and odor and generate hazardous oxidation by-products during the treatment, mainly chloramines and trihalomethanes (THM). These chemicals are established mutagens and carcinogens, arising from reactions between chlorine and amines or chlorine and organic matter, respectively, and mainly affect the gastrointestinal tract (Kimbrough and Suffet, 2002). Also, long-time exposure to chlorite causes anemia and a significant increase in methaemoglobinemia (Condie, 1990).

Electrochemical treatment is an efficient method for the removal of pathogens. The method was used for disinfection in food processing from neutral electrolyzed water containing active chlorine (Deza et al., 2003), to promote the inactivation of Legionella in circulating water with $0.1 \% \mathrm{NaCl}$ used in cultivation of germinated brown rice (Feng et al., 2004) and in medical applications (Tsuji et al., 2000). Diao et al. (2004) tested $E$. coli disinfection by various treatments, including chlorination, ozonation, Fenton reaction and electrochemical disinfection using $500 \mathrm{mg} \mathrm{L}^{-1}$ of $\mathrm{NaCl}$ as electrolyte. Scanning electron microscopy analysis suggested that the electrochemical treatment had a greater effect than the other disinfection processes examined.

Various electrode materials have been tested for electrochemical water disinfection, with a focus on the applied cell potentials and killing mechanisms. Experiments comparing the performance of anodic materials have been carried out with oxide electrodes (Inazaki et al., 2004; Bergmann and Koparal, 2005), titanium nitride (Matsunaga et al., 2000), carbon, activated carbon fiber (Matsunaga et al., 1992; Matsunaga et al., 1994), stainless-steel (Angelis et al., 1998; Regis and Bidoia, 2005), cast-iron (Bratfich et al., 1999), platinum-iridium (Nakajima et al., 2004), platinum-clad niobium mesh (Kerwick et al., 2005), palladium-coated carbon cloth (Sadamura et al., 2000), doped diamond (Panizza and Cerisola, 2005), etc. However, the most of these materials are only conventional for scientific purposes, but not available in large-scale or economically interesting for engineering applications. Also, most of the works are in batch mode, taking to fouling on electrodes surface. There are some other methods related to electrolysis or electrical current effects such as disinfection using metal ions generated by electrolytic processes (Khaydarov et al., 2004), electric inactivation of bacteria in sea water and saline wastewater (Park et al., 2003; Li et al., 2002) and electrolytic generation of biocides (Zinkevich et al., 2000).

Oxide-coated electrodes are used in many studies of electrochemical treatment of water containing organic pollutants and are known as Dimensionally Stable Anodes (DSA). The use of DSA in large-scale water-treatment systems is favored by the ready accessibility of this technology from the chlorine-alkali industry, where they are employed in electrolyzers.

Electrolytic treatment can help the chlorination process because the addition of large amount of chemicals is not necessary. The process is easy to automate, versatile, requires only a small area of treatment plant and can have low cost. The number of applications of electrolysis with oxide-coated electrodes is growing, for example, in municipal water treatment plant, pharmaceutical effluent remediation, oil refinery waste, landfill leachate and others (Inazaki et al., 2004; Moraes and Bertazzoli, 2005). Besides the advantages to public health of not requiring the addition of potentially toxic chemicals, it is an especially clean process, since the electron is the main reactant.

The aim of this work was design and test a onecell electrochemical reactor for the treatment of water artificially contaminated with $E$. coli. Also, system's efficacy through electrochemical effect exclusively in the absence of chlorine compounds was studied.

\section{MATERIALS AND METHODS}

\section{Bacteria and culture}

Gram-negative E. coli (CCT-1457) was used as a model for disinfection studies. The cells were cultured aerobically at $35^{\circ} \mathrm{C}$. Before tests, a $1 \mathrm{~mL}$ aliquot was transferred to $100 \mathrm{~mL}$ of nutrient broth, which consisted of $3 \mathrm{~g}$ beef extract, $10 \mathrm{~g}$ peptone and 1.5 sodium chloride in $1000 \mathrm{~mL}$ water (Difco, 1998). The culture was shaken in a B.O.D. incubator (Marconi model MA403) at $28^{\circ} \mathrm{C}$ for 24 h. Aliquots of $15 \mathrm{~mL}$ of this culture were centrifuged at $80 \mathrm{rpm}$ for $10 \mathrm{~min}$, washed in deionized water containing $0.08 \mathrm{M} \mathrm{Na}_{2} \mathrm{SO}_{4}$ (Merck P.A.) and resuspended in $15 \mathrm{~mL}$ of $\mathrm{Na}_{2} \mathrm{SO}_{4}$ solution, to give the inoculum for disinfection tests. 
To determine the cell number, the inoculum suspensions were serially diluted and suitable dilutions spread uniformly on a nutrient agar plate. After $72 \mathrm{~h}$ incubation at $37^{\circ} \mathrm{C}$, the colonies were counted and the initial number of bacteria was calculated from the dilution and volume plated. In all counts, at least three replicate plates were used.

\section{Culture in buffered solution}

Cells were cultured as described in 2.1 for the buffered solution test, except that $0.1 \mathrm{M}$ phosphate buffer was used to wash the cells and as the reactor medium. The sterile $0.1 \mathrm{M}$ phosphatebuffered solution ( $\mathrm{pH}$ 7.0, chloride-free) was prepared from $20.699 \mathrm{~g} \mathrm{NaH}_{2} \mathrm{PO}_{4} \cdot \mathrm{H}_{2} \mathrm{O}$ (Merck P.A.) plus $21.310 \mathrm{~g} \mathrm{Na}_{2} \mathrm{HPO}_{4}$ (Merck P.A.) in $3 \mathrm{~L}$ of deionized water. This solution presented a conductivity of $5.39 \mathrm{mS} \mathrm{cm}^{-1}$.

\section{Solution of electrolyzed $\mathrm{Na}_{2} \mathrm{SO}_{4}(0.08 \mathrm{M})$ added} to the inoculum to test residual effect

In these tests, $3 \mathrm{~L}$ of deionized water containing $0.08 \mathrm{M} \mathrm{Na}_{2} \mathrm{SO}_{4}$ (Merck P.A.) was electrolyzed for $60 \mathrm{~min}$ at $75 \mathrm{~mA} \mathrm{~cm}$ and a flow rate of $200 \mathrm{Lh}^{-1}$. After electrolysis, $8 \mathrm{~mL}$ of this solution was added to $2 \mathrm{~mL}$ of E. coli suspension (approximately $10^{6}$ cells) in $0.08 \mathrm{M} \mathrm{Na}_{2} \mathrm{SO}_{4}$ in a test tube. Aliquots were taken at $0,5,15,30,45$ and $60 \mathrm{~min}$. The initial conductivity was $8.30 \mathrm{mS} \mathrm{cm}^{-1}$.

\section{Apparatus}

A schematic diagram of the treatment system is shown in Figure 1. It consisted of a singlecompartment electrochemical reactor, a hydraulic pump to circulate the solution, a flow meter, a $5 \mathrm{~L}$ reservoir, pipes and valves. The components of the electrolytic cell were housed in a metal structure of dimensions $0.7 \mathrm{~m} \mathrm{x} 0.4 \mathrm{~m} \mathrm{x} 1.0 \mathrm{~m}(1 \times \mathrm{w} \mathrm{x} \mathrm{h})$. The apparatus was operated in batch recirculation mode and all the experimental runs were carried out with $3 \mathrm{~L}$ of solution.

Electrolysis was performed with a low-voltage power source (Dawer FCC - 3005D), a DSA rectangular electrode of titanium (reaction area 40 $\mathrm{cm}^{2}$ ), coated with an oxide layer of $70 \% \mathrm{TiO}_{2}$ and $30 \% \mathrm{RuO}_{2}(\mathrm{w} / \mathrm{w})$, and a stainless-steel 304 cathode (3 $\mathrm{mm}$ from anode) installed in the singlecompartment reactor made of PVC plates. The DSA is designed for high mechanical strength, high physical and chemical stability over a wide $\mathrm{pH}$-range and insolubility in aqueous media, so that it has a long operational life and is not toxic
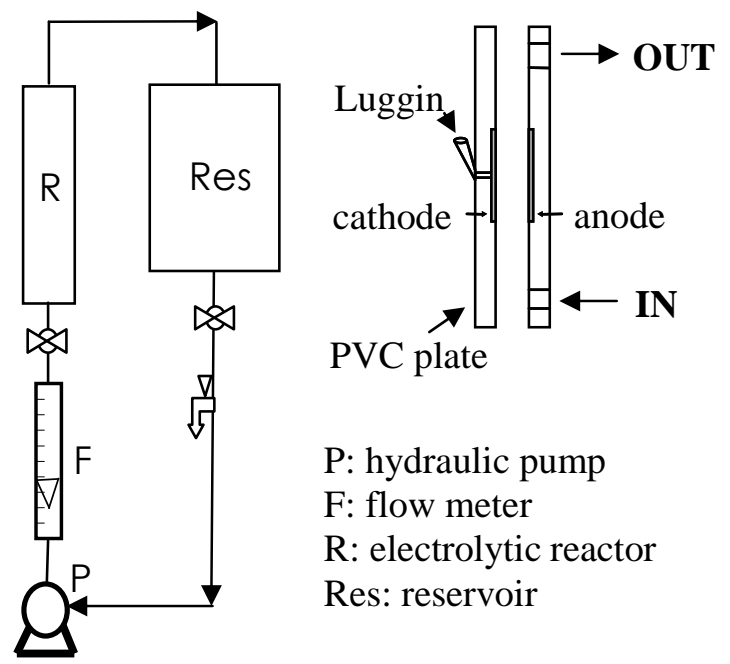

Figure 1 - Schematic diagram of the electrochemical system and illustrative view of the electrolytic reactor cell (right side).

\section{Preparation of solutions and analytical procedures \\ Cell suspensions for electrolysis were obtained by adding $2 \mathrm{~mL}$ of inoculum to $3 \mathrm{~L}$ of deionized}

water containing $200 \mathrm{mg} \mathrm{L}^{-1}$ of $\mathrm{Na}_{2} \mathrm{SO}_{4}$, giving an initial density of $\sim 10^{6}$ cells $\mathrm{mL}^{-1}$ in the circulating system. No other reactants were added to the solution prior to the experiments. The suspensions 
of bacterial cells were initially electrolyzed at constant current densities of 25,50 and $75 \mathrm{~mA} \mathrm{~cm}^{-}$ ${ }^{2}$ (corresponding to direct currents of $1 \mathrm{~A}, 2 \mathrm{~A}$ and $3 \mathrm{~A}$ respectively), at the flow rates of $200 \mathrm{~L} \mathrm{~h}^{-1}$ and $500 \mathrm{~L} \mathrm{~h}^{-1}$ in batch recirculation mode. Samples were collected during the runs at $0,5,15,30,45$, $60 \mathrm{~min}$ and the $\mathrm{pH}$, conductivity, temperature and colony forming units ( $\left.\mathrm{CFU} \mathrm{mL}^{-1}\right)$ were determined. Survival rate was defined as (viable count after electrolysis at a determined time)/(viable count before electrolysis) x 100. All the samples, including the control sample $\left(\mathrm{t}_{0}\right)$, were counted randomly after electrolytic treatment.

Electrolysis experiments were carried out initially in unbuffered solution with chlorine-free $0.08 \mathrm{M}$ sodium sulphate, to determine the inactivation efficacy of the reactor without the generation of chlorine. The current densities and flow rate were varied. Also, the influence of $\mathrm{pH}$ on the inactivation rate was studied, by using $0.1 \mathrm{M}$ phosphate buffer to avoid $\mathrm{pH}$ changes during the experiment. All the reagents were P.A. grade.

\section{Analyses}

The $\mathrm{pH}$ was measured with a UB-10 $\mathrm{pH}$ meter (Denver Instrument) and conductivity with a CA 150 conductivity meter (Tecnopon Ltd). The temperature was taken with a mercury thermometer and colonies were counted on a CP600 colony counter (Tecnal Ltd).

\section{RESULTS AND DISCUSSION}

\section{Electrochemical disinfection of unbuffered solution}

The effects of various current densities on the survival rate of $E$. coli (at a flow rate of $200 \mathrm{~L} \mathrm{~h}^{-1}$ ) are shown in Figure 2. As expected, current density played an important role in the final viability of the cells. E. coli inactivation increased significantly with current density. Thus, $50 \%$ inactivation was observed after $60 \mathrm{~min}$ at a voltage of $3.7 \mathrm{~V}$ and current density of $25 \mathrm{~mA} \mathrm{~cm}^{-2}$ (power consumption rate of $1.27 \mathrm{kWh} \mathrm{m}^{-3}$ ), while at 50 $\mathrm{mA} \mathrm{cm}-2(4.60 \mathrm{~V})$, after $60 \mathrm{~min}$, the survival was reduced to just $10 \%$.

At a flow rate of $200 \mathrm{~L} \mathrm{~h}^{-1}$ and $75 \mathrm{~mA} \mathrm{~cm}^{-2}$ the inactivation was $98.9 \%$ in $60 \mathrm{~min}$, demonstrating that significant disinfection levels could be achieved without the generation or addition of chlorine. Figure 2 illustrate the normalized plot of bacteria inactivation as function of time. Considering an initial concentration of $8.80 \times 10^{6}$ CFU $\mathrm{mL}^{-1}$, the disinfection levels obtained were not sufficient for drinking water treatment. The low power consumption needed to achieve these levels was a notable feature of this system and it can be used as complementary method, reducing the total costs of treatment. Table 1 shows the flow rate $(\mathrm{Q})$, current density $(\mathrm{J})$, voltage $(\mathrm{U})$, initial bacterial cell density $\left(\mathrm{C}_{\mathrm{i}}\right)$, inactivation rate constant $(\mathrm{k})$ and power consumption rate $(\varepsilon)$ calculated for the experimental runs.

In order to test the influence of flow rate on the inactivation rate constant, the tests were also run at $500 \mathrm{~L} \mathrm{~h}^{-1}$.

Electrolysis at $25 \mathrm{~mA} \mathrm{~cm}{ }^{-2}$ and flow rate of $500 \mathrm{~L}$ $\mathrm{h}^{-1}$ reduced the survival rate by $50 \%$, while at a current density of $50 \mathrm{~mA} \mathrm{~cm}$, the viability fell $78 \%$ in $60 \mathrm{~min}$ of processing. In the experiment at $75 \mathrm{~mA} \mathrm{~cm}^{-2}(5.60 \mathrm{~V})$, the survival rate of $E$. coli decreased by $85 \%$. The Figure 3 shows the normalized plot of bacteria inactivation as function of electrolysis time.

The calculated values of inactivation rate-constant showed that this parameter was slightly influenced by the flow rate variation, better results being observed at $200 \mathrm{~L} \mathrm{~h}^{-1}$. However, in all the situations, higher currents values increased the disinfectant capacity and inactivated the bacteria more rapidly. The results obtained here allowed kinetic analyses to be performed, furnishing an inactivation rate-constant, which depended on the operational parameters such as current density, anode area, geometry and flow rate, and could be useful for process scale-up.

To evaluate the inactivation rates for the configuration used in this system, the kinetic study was based on data presented in Figures 2 and 3. The apparent first-order inactivation rate-constant (k), at a flow rate of $200 \mathrm{~L} \mathrm{~h}^{-1}$, was obtained from equation 1 (the decay curve for an exponential-like profile). Data were fitted to this equation and the correlation coefficients consistently exceeded 0.99 . Thus, the solution of the differential equation for inactivation could be written as:

$$
\ln C_{(t)}-\ln C_{(0)}=-k \frac{A}{V} t
$$

Where: $\mathrm{C}_{(\mathrm{t})}$ is the viability in $\mathrm{CFU} \mathrm{mL} \mathrm{m}^{-1}$ counted at time $\mathrm{t}, \mathrm{C}_{(\mathrm{o})}$ is its initial value, $\mathrm{A}$ is the electrode area $\left(40 \mathrm{~cm}^{2}\right), \mathrm{V}$ is the volume of the processed solution $(3 \mathrm{~L}), \mathrm{t}$ is the treatment time and $\mathrm{k}$ is the 
apparent empirical constant of inactivation. The slope of the plot of $\ln \left(\mathrm{C}_{(\mathrm{t})} / \mathrm{C}_{(0)}\right)$ versus $t$ is thus the kinetic constant for inactivation (factor $-\mathrm{k} \mathrm{A} \mathrm{V}^{-1}$ ). From this equation, $\mathrm{k}$ has units of velocity. From the $\mathrm{k}$ values and equation 1, it is possible to extend the scale of the system.

Similar analysis also showed a modification in the decay profile at a higher flow rate. While low flow rate recirculation led to first-order decay, electrolysis at $500 \mathrm{~L} \mathrm{~h}^{-1}$ resulted in zero-order decay (i.e. concentration-independent), after the first $5 \mathrm{~min}$. Additionally, also was evaluated the linear velocity $(v)$ and residence time $(\tau)$. The $v$ was 0.37 and $0.93 \mathrm{~m} \mathrm{~s}^{-1}$ and the $\tau$ was 0.21 and $0.09 \mathrm{~s}$ for $200 \mathrm{~L} \mathrm{~h}^{-1}$ and $500 \mathrm{~L} \mathrm{~h}^{-1}$, respectively.

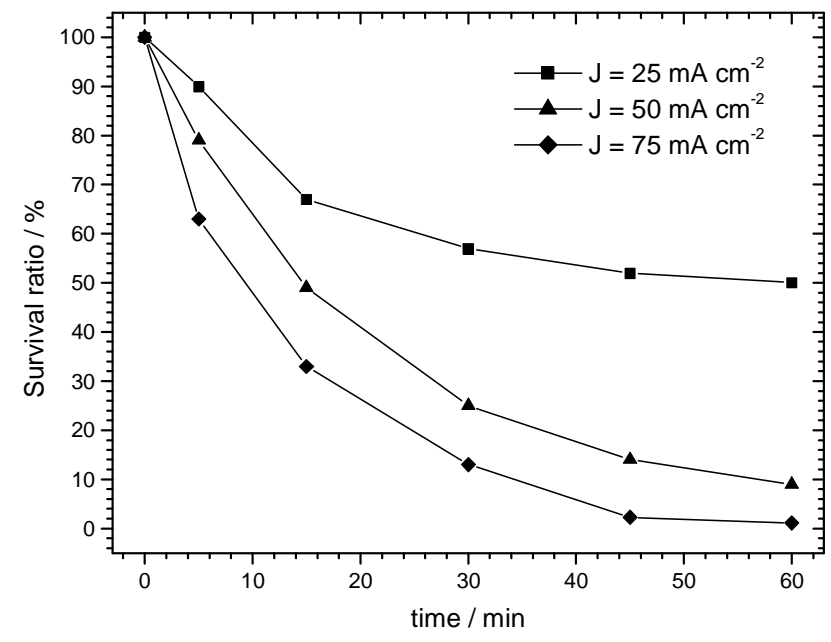

Figure 2 - Survival rate of $E$. coli as a function of electrolysis time. Flow rate of $200 \mathrm{~L} \mathrm{~h}^{-1}$. [E. coli $]_{0}=10^{6} \mathrm{CFU} \mathrm{mL}{ }^{-1} ;\left[\mathrm{Na}_{2} \mathrm{SO}_{4}\right]_{0}=0.08 \mathrm{M}$.

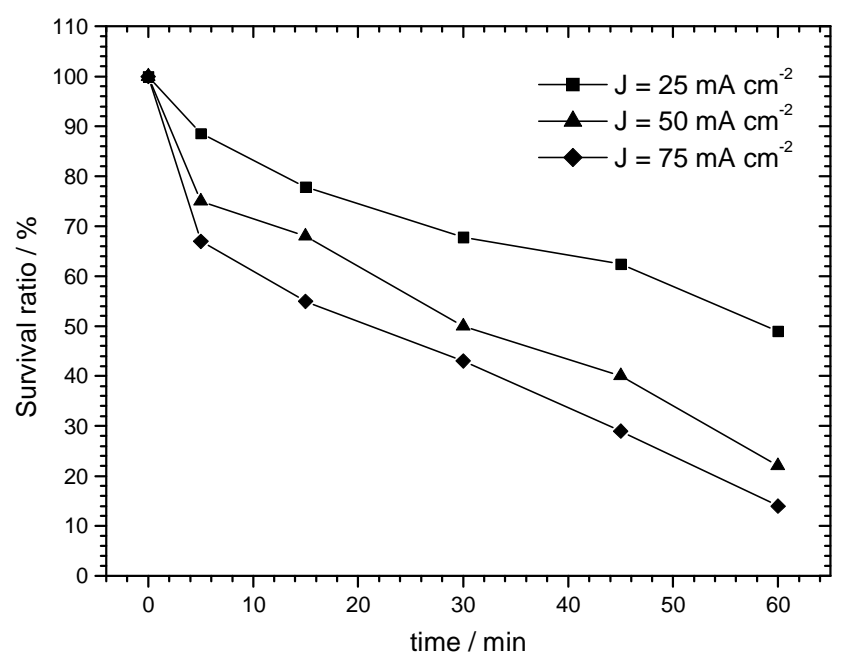

Figure 3 - Survival rate of $E$. coli as a function of electrolysis time. Flow rate of $500 \mathrm{~L} \mathrm{~h}^{-1}$. [E. coli $]_{0}=10^{6} \mathrm{CFU} \mathrm{mL}{ }^{-1} ;\left[\mathrm{Na}_{2} \mathrm{SO}_{4}\right]_{0}=0.08 \mathrm{M}$. 
Table 1 - Flow rate $(Q)$ in $\mathrm{L} \mathrm{h}^{-1}$, current density $(\mathrm{J})$ in $\mathrm{mA} \mathrm{cm} \mathrm{cm}^{-2}$, voltage $(\mathrm{U})$ in volts, initial bacterial viable count $\left(\mathrm{C}_{\mathrm{i}}\right)$ in CFU mL $\mathrm{mL}^{-1}$, inactivation rate constant $(\mathrm{k})$ in $\mathrm{m} \mathrm{s}^{-1}$ and power consumption rate for $60 \mathrm{~min}\left(\varepsilon_{60}\right)$ in $\mathrm{kWh} \mathrm{m}^{-3}$, calculated for the experiments.

\begin{tabular}{cccccc}
\hline $\mathbf{Q}$ & $\mathbf{J}$ & $\mathbf{U}$ & $\mathbf{C}_{\mathbf{i}}$ & $\mathbf{k}$ & $\boldsymbol{\varepsilon}_{\mathbf{6 0}}$ \\
\hline \multirow{2}{*}{200} & 25.0 & 3.80 & $1.7810^{6}$ & $2.010^{-4}$ & 1.27 \\
& 50.0 & 4.60 & $8.2010^{6}$ & $5.110^{-4}$ & 3.07 \\
& 75.0 & 5.58 & $8.8010^{6}$ & $9.610^{-4}$ & 5.58 \\
\multirow{2}{*}{500} & 25.0 & 3.80 & $1.6810^{6}$ & $1.310^{-4}$ & 1.27 \\
& 50.0 & 4.70 & $1.8110^{6}$ & $2.810^{-4}$ & 3.13 \\
& 75.0 & 5.60 & $1.7810^{6}$ & $3.610^{-4}$ & 5.60 \\
\hline
\end{tabular}

The calculated inactivation rate-constant is a characteristic of the system at the initial concentration range of $10^{6} \mathrm{CFU} \mathrm{mL}^{-1}$. To determine the global system inactivation rate, further tests must be performed with other initial concentrations, current densities and flow rates.

Electrolysis can generate a variety of oxidants in the presence of oxygen, including hydrogen peroxide and ozone, as well as free chlorine and chlorine dioxide when chloride ions are present in the solution. Such oxidants are responsible for most, but not all, of the lethality of the applied direct current (Drees et al., 2003). In this study, however, the inactivation of $E$. coli was not caused by chlorine, because the electrolytic medium did not contain chloride ions. The bactericidal agent under these conditions is believed to be electrosorption and direct electron transfer between the electrode and microorganisms. Similar mechanism disinfection was described by Jeong et al. (2007) which employed Pt anode in buffered solution. The microorganisms could come into contact with the anode surface, be adsorbed on it, and be killed electrically. Probably, irreversible permeability of cell membranes and/or electrochemical oxidation of vital cell constituents are induced by the applied electric field. Thus, when the flow rate was increased, the inactivation rate-constant was slightly diminished because a smaller number of microorganisms were adsorbed on the electrodes. A higher linear velocity results in a smaller residence time and consequently shorter contact time with the electrode, as detailed in Table 1. Residence time was evaluated as the ratio of the volume between the electrodes $(0.3 \mathrm{~cm}$ $\mathrm{x} 40 \mathrm{~cm}^{2}=12 \mathrm{~cm}^{3}$ ) to the flow rate. The linear velocity was calculated from ratio of the flow rate to the electrode area.

Also, it is assumed that the process is affected by the $\mathrm{pH}$ gradient close to the electrodes, due to the formation of hydroxyl radicals $\left(\mathrm{OH}^{\circ}\right)$ and, with lower probability, formation of disinfectant agents such as $\mathrm{H}_{2} \mathrm{O}_{2}$. Fóti et al. (1997) established that physiosorbed hydroxyl radicals, intermediate species produced by the anodic discharge of water, were also responsible for disinfection. During electrolysis, the discharge of water molecules at the surface of the metal-oxide anode $\mathrm{MO}_{\mathrm{x}}$ forms hydroxyl radicals that are physically adsorbed, in accordance with the equation:

$$
\mathrm{MO}_{\mathrm{x}}+\mathrm{H}_{2} \mathrm{O} \longrightarrow \mathrm{MO}_{\mathrm{x}}\left(\mathrm{OH}^{*}\right)+\mathrm{H}^{+}+\mathrm{e}^{-}
$$

Increasing the current density increases the rate of $\mathrm{OH}^{\bullet}$ generation and $\mathrm{pH}$ gradient in the vicinity of the anode. Furthermore, optimal current efficiencies exist, which must be determined by the case studies for specific water qualities. Diao et al. (2004) achieved $99.98 \%$ of $E$. coli disinfection in the presence of $500 \mathrm{mg} \mathrm{L}^{-1}$ of $\mathrm{NaCl}$ using $\mathrm{RuO}_{2}, \mathrm{TiO}_{2}$ and $\mathrm{ZnO}_{2}$ electrodes, due to $\mathrm{OH}^{\bullet}$ formation. Also, the mechanism of disinfection can be interpreted as an electroxidation, such as electrochemical oxidation of coenzyme A or destabilization of the cell by the transfer of charge. Many studies have reported proportionality between free chlorine and the bactericidal effects of electrolysis (Kiura et al., 2002; Nakajima et al., 2004). The present study showed that it was possible to obtain a bactericidal effect without addition of chlorine or chlorinated compounds using $\mathrm{Ti} / 70 \% \mathrm{TiO}_{2} / 30 \% \mathrm{RuO}_{2}$ anode. However, the present work focused on the engineering characteristics of this system, verifying the sanitization effects of electrolysis, rather than on the mechanisms involved.

In the course of these experiments, there was no significant heating due to electrolysis. The temperature increased $5^{\circ} \mathrm{C}$ at most; also, the $\mathrm{pH}$ change observed was around one unit and the conductivity practically did not alter. Since the solutions did not exhibit any marked rise in 
temperature or $\mathrm{pH}$ change following electrolysis, these factors were not responsible for the bactericidal activity.

\section{Electrochemical disinfection in phosphate- buffered solution}

As observed in Figure 4, when $75 \mathrm{~mA} \mathrm{~cm}^{-2}$ was applied at $500 \mathrm{~L} \mathrm{~h}^{-1}$ in the buffered solution, the $E$. coli viability diminished to $50 \%$ within $60 \mathrm{~min}$ of electrolytic treatment. As cited above, in the equivalent test with unbuffered solution, the fall in viability was greater, at about $85 \%$ in $60 \mathrm{~min}$. In the experiment using buffered solution, the bacterial viability was thus affected significantly less, because the $\mathrm{pH}$ gradient was weaker and the inactivation of cells was probably due only to the hydroxyl radicals generated on the anode surface, or by direct charge transfer. The temperature had a maximum variation of $8^{\circ} \mathrm{C}$, and the $\mathrm{pH}$ has not changed, as expected. In all the runs, the variation in the conductivity was negligible. The flow rates values used were initially chosen to enable the use of the method on small-scale applications, and also for being well known that the oxidation of organic compounds in electrochemical systems was better at higher values of linear velocity.

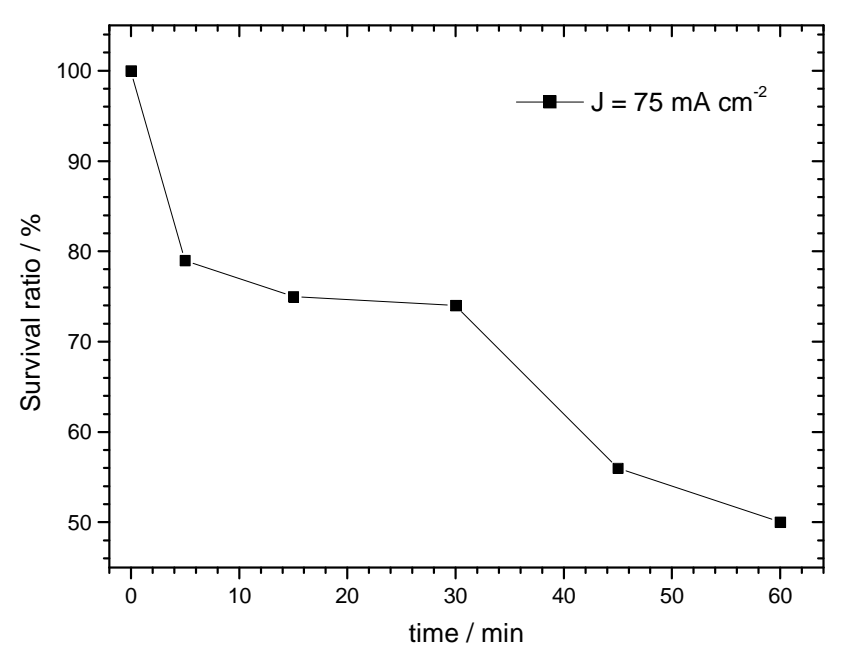

Figure 4 - Survival rate of E. coli as a function of electrolysis time in buffered solution. Flow rate of 500 $\mathrm{L} \mathrm{h}^{-1}$. $[\text { E. coli }]_{0}=10^{6} \mathrm{CFU} \mathrm{mL}{ }^{-1} ;[\text { Phosphate buffer }]_{0}=0.1 \mathrm{M}$.

During the electrolysis, bacteria can suffer oxidative stress, caused by the intermediates that react with oxygen, superoxide anions $\left(\mathrm{O}_{2}{ }^{\circ}\right), \mathrm{H}_{2} \mathrm{O}_{2}$ and hydroxyl radicals, causing damage to proteins, nucleic acids and cellular membranes and culminating in cell death (Rincon and Pulgarin, 2005). Tolentino-Bisneto and Bidoia (2003) sugested that the discharge from the electrodes causes microorganism's death by cellular lysis due to the electroporation in the cell membrane.

\section{Disinfection residual effect of electrolyzed solution}

In the test using a sodium sulphate solution electrolyzed without the bacterial suspension and later added to the inoculum, the viability of the $E$. coli was around $52 \%$ after 60 min. (Fig. 5). The $\mathrm{pH}$ and the conductivity did not suffer significant change. In this case, cell inactivation was probably due to the action of oxidizing agents that produced a residual effect, because the cells had no contact with the electrode surface. Moreover, the percentage of unviable cells was practically equal to that of the electrolyzed buffered suspension; i.e., when the $\mathrm{pH}$ gradient effect near the electrode was minimized, the decrease in bacterial concentration was similar to that observed in the residual effect test. Obviously, based on the decline profile, a major removal of microorganisms would be obtained if the treatment period was larger than $60 \mathrm{~min}$.

Despite its great effectiveness and potential, the killing mechanism of electrochemical disinfection using titanium oxide anode is still an unsettled issue. A number of theories have been proposed to explain the main bactericidal processes and 
increasing attention has recently been given to the role of free radicals, although more evidence remains to be collected. Jeong et al. (2006) studied the $E$. coli inactivation on boron-doped diamond electrode and in Pt anode (Jeong et al., 2007). The authors observed inactivation in two stages in a similar way to that observed in the electrochemical degradation of the organic pollutants. Kerwick et al. (2005) studied the inactivation of E. coli and bacteriophage $M S 2$ using platinum clad niobium mesh anode and concluded that the $\mathrm{OH}$ radical was the responsible by the microorganism inactivation. The generated oxidizing agents and/or disinfection mechanisms presented by
Jeong et al. (2006 and 2007), Kerwick et al. (2005) and Delaedt (2008) are not fully applicable to DSA anodes, which can promote selective oxidation for organics.

Delaedt et al. (2008) carried out tests using a commercial electrolysis cell equipped with coated titanium electrodes to study the residual effect of electrolysis on tap water containing $45 \mathrm{mg} \mathrm{L}^{-1}$ of chloride which contained $10^{4} \mathrm{CFU} \mathrm{mL} \mathrm{m}^{-1}$ of E. coli. The residual effect led to complete eradication of cultivable $E$. coli when at least a free oxidant concentration of $0.08 \mathrm{mg} \mathrm{L}^{-1}$ was still present after reaction time. The authors did not state theory or mechanisms to explain the residual effect.

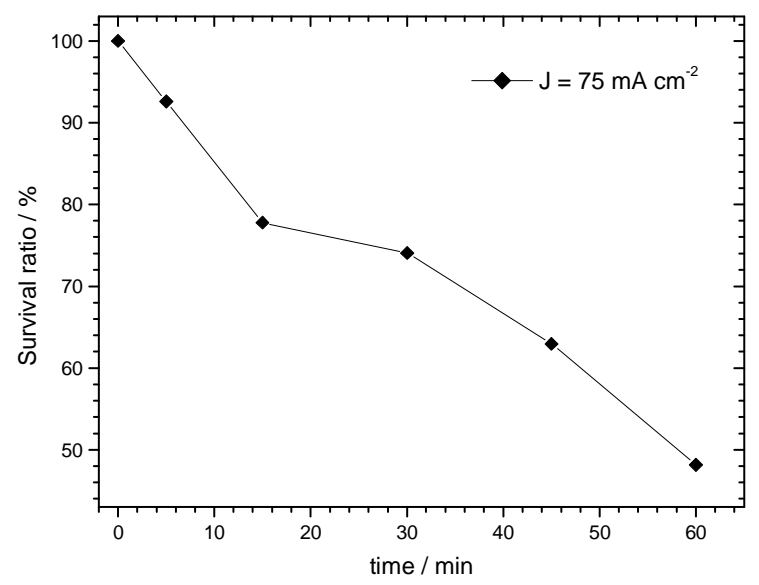

Figure 5 - Survival rate of $E$. coli as a function of electrolysis time. Flow rate of $200 \mathrm{~L} \mathrm{~h}^{-1}$. [E. coli $]_{0}=10^{6} \mathrm{CFU} \mathrm{mL}{ }^{-1} ;[\text { E. coli }]_{0}=10^{6} \mathrm{CFU} \mathrm{mL}^{-1} ;\left[\mathrm{Na}_{2} \mathrm{SO}_{4}\right]_{0}=0.08 \mathrm{M}$.

To conclude, the results obtained demonstrated that the electrolytic process operating in batchrecirculation mode, using a $\mathrm{Ti} / 70 \% \mathrm{TiO}_{2} / 30 \% \mathrm{RuO}_{2}$ anode, was effective in decreasing the viability of E. coli (CCT-1457). The best results were obtained by applying a current density of $75 \mathrm{~mA} \mathrm{~cm}$. It was observed that increasing the current density and/or electrolysis time resulted in a rise in the inactivation rate. Raising the flow rate slightly impaired the E. coli inactivation. It was assumed that this sanitization process resulted from the damage caused by the $\mathrm{pH}$ gradient near the electrode and from the formation of free shortlived reactive species, such as $\mathrm{OH}^{\bullet}$. However, the inactivation levels achieved in $60 \mathrm{~min}$ were not sufficient to reach the drinking water standards.
The results showed that from relatively small-scale experiments, the application of modest cell potentials to DSA anodes enhanced the disinfection rates and the concept could be extended to reactors capable of larger-scale operation. Larger reactors can be produced simply by increasing the number of electrode cassettes and maintaining the power consumption rate.

Considering the number of cells inactivated by the electrolytic process, the proposed system could not be applied as unique treatment in $60 \mathrm{~min}$ of processing, but in combination with other methods, such as UV disinfection or chlorination. The present results implied that the techniques relying upon direct current to reduce the numbers of microbes in water could, following the 
optimization of the system by further studies, become efficient means of reducing the numbers of potentially pathogenic bacteria and ensuring the safety of the treated water.

\section{ACKNOWLEDGEMENTS}

The authors are grateful to CNPQ, FAPESP; FUNDUNESP, DeNORA DO BRASIL Ltda and TIGRE Tubos e Conexões S.A. (Brazil).

\section{RESUMO}

Água contaminada é uma das maiores origens de doenças em seres humanos. Em todo o mundo, a cloração é o método mais utilizado para promover desinfecção em águas de abastecimento devido ao seu efeito residual, quando adequadamente calculado. Contudo, se a água apresentar matéria orgânica, pode haver a geração de organoclorados, os quais são genotóxicos e carcinogênicos. Sob esta óptica, investigamos o efeito bactericida da aplicação da eletrólise em água sem cloro contaminada com Escherichia coli (CCT-1457). O objetivo deste estudo foi avaliar o poder de desinfecção e o comportamento cinético da eletrólise realizada em reator de compartimento único e usando eletrodos ADE (Anodo Dimensionalmente Estável), visando ampliação de escala. Uma suspensão contendo elevada concentração de E. coli $\left(10^{6}\right.$ UFC $\left.\mathrm{mL}^{-1}\right)$ foi submetida ao tratamento no reator em 25,50 e 75 $\mathrm{mA} \mathrm{cm}{ }^{-2}$ durante $60 \mathrm{~min}$, em vazões de 200 e 50 $\mathrm{Lh}^{-1}$. A taxa de inativação foi aproximadamente 99\% para a solução isenta de compostos clorados, com consumo de energia elétrica menor que 5,60 $\mathrm{kWh} \mathrm{m}{ }^{-3}$ em $200 \mathrm{~L} \mathrm{~h}^{-1}$ e $75 \mathrm{~mA} \mathrm{~cm}^{-2}$. Uma solução de $\mathrm{Na}_{2} \mathrm{SO}_{4} \quad 0,08 \mathrm{M}$ eletrolisada e adicionada posteriormente ao inoculo apresentou efeito residual bactericida. A eficiência da desinfecção foi regida pelo tempo de contato e pela densidade de corrente aplicada, e foi realizado um estudo cinético que permite a ampliação de escala.

\section{REFERENCES}

Angelis, D.F., Corso C.R., Bidoia E.D., Moraes, P.B., Domingos, R.N., Rocha-Filho, R.C. (1998), Eletrólise de resíduos poluidores: I - Efluente de uma indústria liofilizadora de condimentos. Química Nova, 21, 20.

Bergmann, M.E.H.; Koparal, A.S. (2005), Studies on electrochemical disinfectant production using anodes containing $\mathrm{RuO}_{2}$. J. App. Electrochem. 35, 1321.

Bratfich, O.J., Domingos, R.N., Angelis, D.F., Bidoia, E.D. (1999), Electrolysis of cell suspensions of Bacillus subtilis (ATCC-9372) and of Saccharomyces cerevisiae using cast-iron electrodes. Braz. J. Ecol. 3, 83.

Condie, L.W. (1990), Toxicological effects associated with drinking water disinfectants and their byproducts. In: R.L. Joley, L.W. Condie, J.D. Jonson, S. Katz, R.A. Minear, V.A. Jacobs, Eds., Water Chrorination Chemistry, Environmental Impacts and Health, v.6, p. 281. Boca Raton: Lewis Publishers.

Deza, M.A., Araújo, M., Garrido, M.J. (2003), Inactivation of Escherichia coli O157:H7, Salmonella enteritidis and Listeria monocytogenes on the surface of tomatoes by neutral electrolyzed water. Let. Applied Microbiol. 37, 482.

Diao, H.F., Li, X.Y., GU, J.D., Shi, H.C., Xie, Z.M. (2004), Electron microscopic investigation of the bactericidal action of electrochemical disinfection in comparison with chlorination, ozonation and Fenton reaction. Proc. Biochem. 39, 1421.

Delaedt, Y.; Daneels, A.; Declerck, P.; Behets, J.; Ryckeboer, J.; Peters, E.; Ollevier, F. (2008), The impact of electrochemical disinfection on Escherichia coli and Legionella pneumophila in tap water. Microbiol. Res. 163, 192.

Difco Manual (1998), Dehydrated Culture Media and Reagents for Microbiology. $11^{\text {th }}$ ed. Difco Laboratories: Sparks, MD, 862 p.

Drees, K.P., Abbaszadega, M., Maier, R.M. (2003), Comparative electrochemical inactivation of bacteria and bacteriophage. Water Res. 37, 2291.

Feng, C., Suzuki, K., Zhao, S., Sugiura, N., Shimada, S., Maekawa, T. (2004), Water disinfection by electrochemical treatment. Biores. Technol. 94, 21.

Fóti, G., Gandini, D., Comninellis, C. (1997), Anodic oxidation of organics on thermally prepared oxide electrodes. Curr. Top. Electrochem. 5, 71.

Inazaki, T. H., Pião, A. C. S., Bidoia, E. D. (2004), Treatment of simulated wastewater containing $n$ phenyl-n-isopropyl-p-phenylenediamine using electrolysis system with $\mathrm{Ti} / \mathrm{TiRuO}_{2}$ electrodes. Braz. Arch. Biol. Technol. 47, 983. 
Jeong, J., Kim, J.Y., Yoon, J. (2006), The role of reactive oxygen species in the electrochemical inactivation of microorganisms. Environ. Sci. and Technol. 40, 6117.

Jeong, J., Kim, J.Y., Cho, M., Choi, W., Yoon, J. (2007), Inactivation of Escherichia coli in the electrochemical disinfection process using a Pt anode. Chemosphere. 67, 652.

Kalisvaart, B.F. (2004), Re-use of wastewater: preventing the recovery of pathogens by using medium-pressure UV lamp technology. Water Sci. and Technol. 50, 337.

Kerwick, M.I., Reddy, S.M, Chamberlain, A.H.L., Holt, D.M. (2005), Electrochemical disinfection, an environmentally acceptable method of drinking water disinfection? Electrochimica Acta. 50, 5270.

Khaydarov, R.R., Olsen, R.L., Rogers, S.E. (2004), Water disinfection using electrolytically generated silver, copper and gold ions. J. Water Sup. Res. and Technol.- Aqua, 53, 567.

Kimbrough, D.E. and Suffet, I.H. (2002), Electrochemical removal of bromide and reduction of THM formation potential in drinking water. Water Res. 36, 4902.

Kiura, H., Sano, K., Morimatsu, S., Nakano, T. Morita, C., Yamaguchi, M., Maeda, T., Katsuoka, Y. (2002), Bactericidal activity of electrolyzed acid water from solution containing sodium chloride at low concentration, in comparison with that at high concentration. J. Microb. Meth. 49, 285.

Li, X.Y., Ding, F., Lo, P.S.Y., SIN, S.H.P. (2002), Electrochemical disinfection of saline wastewater effluent. J. Environ. Eng.- ASCE, 128, 697.

Lubicki, P. and Jayaram, V.S. (1997), High voltage pulse application for the destruction of the Gramnegative bacterium Yersinia enterocolitica. Bioelectrochem. and Bioenerg. 43, 135.

Matsunaga, T., Nakasono, S., Takamuku, T., Burgess, J.G., Nakamura, N. Sode, K. (1992), Disinfection of drinking water by using a novel electrochemical reactor employing carbon-cloth electrodes. Appl. Environ. Microbiol. 58, 686.

Matsunaga, T., Nakasono, S., Kitajima, Y., Horiguchi, K. (1994), Electrochemical disinfection of bacteria in drinking-water using activated carbon-fibers. Biotechnol. and Bioeng. 43, 429.

Matsunaga, T., Okochi, M., Takahashi, M., Nakayama, T., Wake, H., Nakamura, N. (2000), Tin electrode reactor for disinfection of drinking water. Water Res. 34, 3117.
Moraes, P.B. and Bertazzoli, R. (2005), Electrodegradation of landfill leachate in a flow electrochemical reactor. Chemosphere, $\mathbf{5 8}, 41$.

Nakajima, N., Nakano, T., Harada, F., TANIGUCHI, H., Yokoyama, I., Hirose, J., Daikoku, E., Sano, K. (2004), Evaluation of disinfective potential of reactivated free chlorine in pooled tap water by electrolysis. J. Microbiol. Met. 57, 163.

Panizza, M. and Cerisola, G. (2005), Application of diamond electrodes to electrochemical processes. Electrochimica Acta 51, 191.

Park, J.C., Lee, M.S., Lee, D.H., Park, B.J., Han, D., Uzawa, M., Takahatori, K. (2003), Inactivation of bacteria in seawater by low-amperage electric current. App. Environ. Microbiol. 69, 2405.

Regis G, Bidoia E.D. (2005), Electrolytic treatment applied to the industrial effluent containing persistent wastes monitored by Bartha respirometric assays. Braz. Arch. Biol. Technol. 48, 319.

Rincon, A.G. and Pulgarin, C. (2005), Use of coaxial photocatalytic reactor (CAPHORE) in the $\mathrm{TiO}_{2}$ photo-assisted treatment of mixed E. coli and Bacillus $s p$ and bacterial community present in wastewater. Catal. Today 101, 331.

Sadamura, H., Kobayashi, S., Honda, S., Suzuki, N., Kogure, M., Hamashima, H., Kanzaki, Y. (2000), Electrochemical disinfection of microorganisms using palladium coated carbon cloth electrodes. Electrochem. 68, 321.

Szewzyk, U., Szewzyk, R., Manz, W., Schleifer, K.H. (2000), Microbiological safety of drinking water. Annu. Rev. Microbiol. 54, 81.

Tolentino-Bisneto, R. and Bidoia E. D. (2003), Effects of the electrolytic treatment on Bacillus subtilis. Braz. J. Microbiol. 34, 48.

Tsuji, S., Kawano, S., Oshita, M., Ohmae, A., Shinomura, Y., Miyazaki, Y., Hiraoka, S., Matsuzawa, Y., Kamada, T., Hori, M., Maeda, T. (2000), Endoscope disinfection using acidic electrolytic water. Endoscopy 31, 528.

Zinkevich, V., Beech, I. B., Tapper, R., Bogdarina, I. (2000), The effect of super-oxidized water on Escherichia coli. J. Hosp. Infec. 46, 153.

Received: September 15, 2008; Revised: April 08, 2009; Accepted: April 21, 2010. 